\title{
Latin American Development and the Globalization Imperative: New Directions, Familiar Crises
}

\author{
David J. Keeling \\ Department of Geography and Geology, Western Kentucky University
}

\begin{abstract}
Globalization has emerged as the defining conceptual and contextual socioeconomic framework of analysis for the early 21 st century. Throughout Latin America, globalization has become a buzzword for profound structural change, as well as the focus of vociferous and rigorous criticism by those sectors of society disadvantaged, damaged, or bypassed by the forces of global restructuring. This article examines the theoretical and practical implications of globalization for Latin America development, analyzes key regional and local conditions, discusses 'glocalization,' and argues for a policy approach that rethinks the extant framework and restructures the analytical context in a more proactive manner.
\end{abstract}

Keywords: Latin America, development, globalization, glocalization, policy

\section{Resumen}

La globalización ha surgido como el marco analítico, conceptual y contextual definitivo para el siglo XXI. En todas partes de América Latina, la globalización ha llegado a ser un cliché para el cambio estructural, como también el foco de una crítica vociferante y rigorosa por aquellos sectores en desventaja, dañados, o evadidos por las fuerzas de la re-estructuración global. Este artículo examina las implicaciones teóricas y prácticas de la globalización para el desarrollo de América Latina, analiza las condiciones locales y regionales, discute "glocalización", y argumenta por una política que reconsidere el marco existente y reestructure el contexto analítico de una manera más proactiva. Palabras claves: América Latina, desarrollo, globalización, glocalización, politica

\section{Introduction}

Throughout Latin America, globalization has emerged as the defining conceptual and empirical phenomenon of the early $21^{\text {st }}$ century. From an evolving trendy perspective on socio-economic change two decades ago, globalization has become the dominant contemporary political-economic framework for national development policy, as well as the focus of vociferous and rigorous criticism by those sectors of society disadvantaged, damaged, or bypassed by the forces of global change. Many Latin American governments have adopted wholeheartedly globalization policies such as privatization, deregulation, neoliberalism, and free trade in an attempt to reverse decades of economic mismanagement and squandered development opportunities. The shift from an ideology of dirigismo (state-directed development) to one of neoliberalismo (state disengagement) has opened up the region to the global capitalist regime of finance, production, marketing, and consumption, which has altered irrevocably the way in which goods and services are 
provided, spatial relationships are structured, and cultural identities are defined and understood.

As globalization evolves into a fully defined theoretical framework, its impacts and implications in Latin America often are discussed from an absolutist perspective and framed almost exclusively within the context of the political state. This is occurring despite a conceptualization of globalization that implies a frictionless world without stateimposed barriers to economic interaction. Economic development policies throughout Latin America, for example, continue to be framed by a conception of national territory as culturally and structurally homogenous, rather than by the reality of socioeconomic spatial heterogeneity that goes beyond artificial internal or international political boundaries. As a result, regions, peoples, and places frequently are reduced to insignificant actors or are omitted from the analysis altogether. Indeed, a central criticism of globalization throughout Latin America has been its role in accelerating social polarization or the 'development gap.' This occurs when an increasing percentage of national income or wealth is concentrated in the hands of fewer people. Increasingly, globalization analysis seems to be driven primarily by macroeconomic statistics that serve as positive indicators of long-term national development trends, while micro-economic data that measure quality of life for individuals and communities are downplayed or dismissed outright as insignificant short-term trends.

This paper examines the implications of globalization for development in Latin America by focusing first on six key long-term forces of change, the 'subsurface' processes that are reshaping the national and regional environments within which globalization operates. Next, it examines six key themes that encapsulate the short-term disruptions experienced by Latin American societies today as a consequence of globalization. Finally, the question is raised about how to mitigate the damage caused by short-term disruptions, while developing meaningful policies that recognize the long-term shifts in the restructuring of Latin American countries and societies, shifts that are being driven by the forces of globalization and neoliberalism. The paper argues ultimately for a policy and management approach based on the concept of 'glocalization' that rethinks the analytical approach to globalization's impacts in a more sensitive, proactive, and spatially relevant manner.

\section{Setting the Stage: The Globalization Thesis}

Globalization is fast becoming the shibboleth for the profound reordering of the world political economic system that has taken place over the past two decades. The term has emerged as the ultimate expression both of an increasingly interconnected global society and of a socio-economic Trojan Horse that will wreak deprivation and degradation on local communities. Some explanations and definitions of globalization argue that it is a process of spatial integration, inclusion, and engagement, while others posit that it is a process of spatial segregation, separation, and exclusion (Bauman, 1998; Lechner and Boli, 2003; Sadowski, 1998). Such a seemingly unresolvable theoretical paradox points to the challenges presented by the globalization thesis: to understand its theoretical and ideological context and to analyze empirically its impacts on people and places. From the vast and rapidly growing literature on globalization, Lechner and Boli (2003) have identified six key questions: Is globalization new? What does globalization involve? Is globalization driven by an expanding market? Does globalization make the world more homogenous? Does globalization determine local events? Is globalization harmful? In order to 
set the stage for an analysis of globalization's implications for development in Latin America, these questions are explored briefly.

First, is globalization new? To answer this question, a distinction should be made between what is known generally as historical globalization and what Lloyd (2000:260) calls 'ultra-modernist' globalization. Historical globalization processes can be traced back at least to the 15th century, with the genesis of the capitalist world economy and the geographic expansion of division of labor, access to raw materials, industrial production, and the circulation of capital. Wallerstein $(1974,1979)$ conceptualized these developments as a single world system divided into three main economic zones: core, semi-periphery, and periphery. Since 1492, Latin America's development has been shaped almost exclusively by the forces of historical globalization, and many critiques of the impacts of these forces (dependency theory, structural Marxism, neoimperialism, regulation theory) have focused on the external causes of underdevelopment driven by the world capitalist system (Cardoso, 1982; Frank, 1969; Prebisch, 1972). Indeed, the power of imperial or core states to create, manipulate, and unify markets at ever greater scales has been a central feature of globalization many times and in myriad places over the millennia (Lloyd, 2000; Schwartz ,1994).

In contrast, ultra-modernist globalization refers to the intensification since the 1980s of the spatial reorganization of production and distribution, the spread of financial markets, the inter-penetration of advanced producer services, and the rise of key cities as command and control centers of global capital (Appadurai, 2003; Lechner and Boli, 2003; Lloyd, 2000; Mittelman, 1994). Although the roots of ultra-modernist globalization are planted firmly in the garden of historical globalization, the contemporary system has matured by the adoption and spread of transport and communication technologies. For the first time in human history, multinational corporations can produce anything anywhere on the planet and can sell anything anywhere on the planet. As Held et al. (1999:15) argued, time-space compression has 'stretched' capital and information activities across the traditional boundaries constructed by political and geographical structures. This theoretically borderless world now presents few impediments to the rapid and efficient movement of people, capital, goods, services, and information, thus facilitating the emergence of a truly global marketplace.

Second, what does globalization involve? Giddens (1990:64) has defined globalization as 'an intensification of world-wide social relations which link distant localities in such a way that local happenings are shaped by events occurring many miles away and vice versa.' In other words, globalization involves changes in the spatial reach of capital, financial activities, advanced producer services, and information that transcend the political state system and where, arguably, multinational corporations replace states and communities as the dominant actors in the global system. In theory, a globalized socioeconomic system would be freer, more efficient, economically rational, and unfettered by state-directed diversions of wealth into unproductive areas. As production is reorganized across time and space, industries interpenetrate across political borders, financial capital spreads across the globe, homogenized consumer goods diffuse to distant markets, and people flow to new areas of economic opportunity, the local and the global will become inextricably intertwined in a system of universal order (Bauman, 1998; Loker, 1999). However, globalization also involves reshaping the social structure of the world system in a way that reinforces social polarization. At the top of the globalization hierarchy are those individuals and communities integrated into the global economy who have command and control functions over global production, finance, and information. In the middle are those who serve the global economy in more precarious employment circum- 
stances, and at the bottom sits the superfluous labor force that represents a potential destabilizing threat to globalization (Cox, 1996).

Third, is globalization driven by an expanding market? The global operation of multi-national corporations has played a major role in the expansion of international trade and the emergence of regional trading blocs since the 1980s. A significant number of treaties, institutions, and organizations aimed at facilitating global trade have come into being in order to 'open up' national markets and local communities to free trade. Thus, there is a reciprocal relationship between an expanding market and the forces of globalization. As capitalism continues to overcome spatial limitations to market expansion through time compression, an expanding market provides a more conducive environment within which globalization processes can spread. One of the arguments supporting the spread of democracy across the planet, for example, is that, theoretically, stable, participatory democracies encourage the expansion of a consuming middle class. In turn, an expanding middle class creates a growing demand for goods and services, thus facilitating an expanding national market. This allows the forces of globalization to maximize capital returns, economies of scale, production systems, and distribution costs by engaging with specific expanding national and regional markets and integrating them into the global economy.

The fourth question asks if globalization makes the world more homogenous and, if so, what are the consequences. Embedded in the ideology of global change is the homogenization or Americanization thesis, which argues that capitalist consumerism has orchestrated the spread of Americanized commercial and media products across the planet, with particular success in developing countries (Friedman, 1999; Tomlinson, 1999). Commodified culture in myriad forms, ranging from Cokes to Big Macs, from Nike to the $\mathrm{NBA}$, and from CNN to Hollywood, has disseminated from the USA to the rest of the world, overwhelming local cultural traits and leaving local communities with few choices in the marketplace (Tomlinson, 2003). Critics of the homogenization thesis argue that globalization is taking multiple paths in local places, giving rise to terms such as 'hybridization,' 'creolization,' and 'glocalization.' In many parts of the world, local entrepreneurs and consumers are using imported cultural products to shape and assert their own unique identities, so much so that globalization's success in promoting capitalist consumerism has spawned multiple local variations of so-called globalized culture (Howes, 1996; Kim 2000; Robertson, 1995; Watson, 1997).

Fifth, does globalization determine local events? There is little doubt that in Latin America and other regions of the world, many governments have responded to the rhetoric of globalization by adopting neoliberal strategies to restructure economies and societies. As a consequence of these policies, many local businesses and communities are exposed to competition from global corporations who often have better financing, technology, advertising, and market reach. For example, research in Argentina has suggested that for every new internationally controlled Walmart or Carrefour supermarket, five thousand local 'mom and pop' operations disappear (Hayes, 1998). Under the influence of the North American Free Trade Agreement (NAFTA), the Mexican Congress changed Article Twentyseven of the constitution to allow the free sale of once-inalienable community or ejido lands and lifted trade and investment barriers to external capital and goods. Rebellion erupted in Mexico's southern state of Chiapas, government price supports for many commodities were abandoned, rural-urban migration accelerated, and falling agricultural prices depressed an already fragile rural economy (Krooth, 1995). Giddens' (1990) argument that as global social relations are restructured, local events are shaped increasingly by external forces and vice versa has much merit.

Finally, is globalization harmful? This is perhaps the most complex question of all 
to address because there are multiple contradictions embedded in the globalization thesis. For example, the socioeconomic elite of most developing countries, who comprise a tiny fraction of a country's population, have integrated into the world system and have become completely globalized. In contrast, many highly developed countries are creating developing world conditions among the bottom tier of their labor hierarchy (Cox, 1996; Sassen, 1998). Throughout the emerging regions of the world, vast segments of society are becoming further impoverished, isolated, and excluded from the socioeconomic opportunities offered by globalization (Kaul, 1999). Other contradictions are the loss of regulatory power by states and the widespread resurgence of attempts to reinforce local religious, ethnic, linguistic, political, and gender identities in the face of wider global forces. Brecher and Costello (1994) have synthesized effectively in a single question the issue of whether or not globalization is harmful: global village or global pillage? The challenge for researchers is to examine both macro-socioeconomic and micro-socioeconomic indicators of development under conditions of globalization to understand the impacts for all segments of society across all possible scales of analysis. This requires a holistic, multidisciplinary approach to development analysis.

Without a doubt, globalization, both as ideology and as process, has transformed the world system in profound and fundamental ways over the past two decades. This is especially true in Latin America, where neoliberal policies in many countries have dismantled state regulation of the economy, opened up the much of the region to globalizing processes, and created a new framework for development, growth, and change. As Korzeniewicz (1997:20) argued, the region's institutional structures are being disassembled at a 'precipitous pace, to be replaced by a deepening differentiation in the arenas of operation of enterprises, states, and households.' How these changes unfold in different places at different times will determine the long-term contribution of globalization to improving the quality of life for all Latin Americans in the $21^{\text {st }}$ century.

\section{Latin American Development under Globalization}

A fundamental difference exists between the economic ideologies or policies of globalization, which are essentially structural and conceptual in nature, and the processes of globalization, which are outcome driven and can be empirically measured. However, there appears to be much confusion throughout the region about the distinction between the two definitions. Over the past two decades, many Latin American governments have embraced the ideologies of globalization uncritically and enthusiastically, but have done very little to convert these ideologies into measurable development improvements for the majority of the population (Rodrik, 1999). This is indicative of Latin America's general economic failures throughout the $20^{\text {th }}$ century in that the region frequently has embraced changing economic philosophies and ideologies and incorporated them into national policy. Yet these policies ultimately have generally failed because of insufficient attention paid to the processes that translate policy into measurable development. For example, let's accept the premise that transport and communication technologies are the engine driving contemporary globalization. Latin American governments, with few exceptions, have recognized explicitly in publications, conferences, policy statements, and electoral rhetoric that transport and communication are crucial to development success and they have promoted a variety of high-profile projects to address national and regional integration (Keeling 2002). Yet by conservative estimates, Latin America suffers from an infrastructural deficit in excess of US\$ one trillion in the transport and communication arena just to bring the region up to a minimum level of support for globalization policies to have any reasonable 
chance of long-term development success. This deficit suggests that a significant problem exists between policy formation and policy implementation in the region. How, then, has Latin American development fared under globalization, what are the fundamental forces of change shaping the region today, and why do so many of the familiar development crises that afflict the region remain unaddressed?

Contemporary or ultra-modernist globalization has emerged from the long-term historical processes that have shaped Latin America's people and places. A useful metaphor for explaining Latin American development in a broader context is provided by plate tectonic theory. Drawn from the physical world, plate tectonic theory is the idea that subsurface convection currents cause continental and oceanic tectonic plates to move, thus causing changes both in the position and surface relief of the oceans and continents. Applying this theory to the socio-economic world, contemporary globalization can be viewed as part of the long-term or tectonic shifts in the socioeconomic forces shaping the world around us. The short-term surface manifestations of these long-term shifts are earthquakes and volcanic eruptions, which can reshape local and regional conditions profoundly and rapidly. Cultural 'earthquakes and volcanic eruptions' generally are shortterm events such as rapid inflation or deflation, war, revolution, coups d'etat, increased social polarization, paradigm shifts, boom and bust cycles, and currency devaluation that have a dramatic and often negative impact on economies and societies (Thurow, 1996).

Long-term movements in tectonic plates are driven by a series of interrelated fundamental physical forces. Continuing the metaphor, the long-term shift in global socioeconomic change towards a condition of ultra-modernist globalization is being driven in Latin America by a number of fundamental forces. In turn, the fundamental forces involved in the globalization process are creating the 'earthquakes and volcanic eruptions' that are reshaping the lives and conditions of people and places in Latin America at the dawn of the 21st century. Drawing on Thurow's (1996) analysis of the future of global capitalism, six fundamental forces can be identified for Latin America. First, the system of state-directed economies that dominated the region for nearly fifty years has ended and neoliberalism is emerging as the dominant economic model. Second, the basic structure of Latin American economies is undergoing a transition from a system based on natural resources to one based on human capital and brainpower. Third, Latin American societies have become predominantly urban in composition, and demographic aging, coupled with economic welfare, is looming as a significant social issue. Fourth, the effects of social polarization in the region are becoming more evident as societies undergo cultural and economic restructuring based on their ability to engage with globalization activities. Fifth, as neoliberal policies and non-interventionist strategies are applied to primary sector export activities, to industrialization, and to urbanization throughout Latin America, increased stress is placed on the physical environment. Finally, as globalization spreads geographically, it exerts change in accessibility and mobility demands through its dependence on the technologies of time-space compression.

\section{The Fundamental Forces of Long-Term Change}

Neoliberal policies adopted throughout Latin America since the 1980s have moved the region's countries and societies in a new economic direction, away from the influences of import-substitution and socialist ideologies and towards the integrative embrace of globalization. This policy paradigm shift involves the replacement of state control over resources, production, and services with privatization strategies, the regulation of financial markets with deregulation and fiscal reform, inflexible labor markets with flexible 
ones, closed domestic markets with open and free trade, and restrictive institutions with more innovative management approaches. Moreover, the transition to a more globalized structure for Latin American economies has coincided with a transformation of the political environment from primarily authoritarian to mostly democratic (Haggard and Kaufman, 1995). Reductions in the power of the state through privatization and deregulation are seen as critical to reducing government inefficiencies and management ineptitude in the economic arena and to providing a more technical, disciplined, and flexible approach to running the national economy (Edwards, 1995; Gwynne and Kay, 2004). Neoliberal reforms have not been uniform throughout the region, however. Considerable and important variations exist both in the pace of neoliberal restructuring (for example, fairly rapid in Chile and Argentina, very slow in Venezuela and Honduras) and in the level of integration with global markets. In addition, the spatial and structural impacts of globalization are displaying significant local, regional, national, and supra-national variations, which suggest that this fundamental force of change is facilitating development divergence rather than convergence.

Countries in the developed world such as the United States, Germany, Britain, and Japan have seen the structure of their economies shift over the past fifty years from a natural resource base to a human brainpower base. Information processing, financial management, marketing, research, biotechnology, and other 'brainpower' activities have replaced smoke-stack industrialization, manufacturing, and similar traditional 'blue-collar' production as the dominant employment sectors of the economy. This transformation of the economic structure also is occurring in Latin America, albeit more slowly and more geographically variegated. Sectoral employment as a percentage of the labor force shifted from agricultural dominance in the 1960 s to tertiary and quaternary dominance (service, information, transportation, marketing, finance, etc.) in the 1990s. In Brazil, for example, fiftyfive percent of the labor force worked in agriculture in 1960; in the 1990s, fiftyfive percent of the labor force worked in the tertiary and quaternary sectors. Mexico has seen the same percentage sectoral shift, as have Colombia, Panama, and Costa Rica (Gwynne and Kay, 2004).

In 2000, the seven highest-income countries in Latin America (Argentina, Brazil, Chile, Colombia, Mexico, Venezuela, and Uruguay) all had over fifty percent of their economically active populations engaged in tertiary and quaternary employment, whereas the percentage of the labor force engaged in traditional industry continued to show a decline (World Bank, 2000). This shift has occurred, in part, because neoliberal policies have removed several of the protections that many companies enjoyed in the domestic market and forced them to become more oriented towards the global market, where competition is fiercer. In addition, labor reforms associated with neoliberalism, particularly in state-owned companies and in the public service sector, have forced many workers to seek jobs in the private formal sector and in export- or globally oriented companies. Job expansion throughout the 1990s was most dynamic in the service or human brainpower sector of Latin American economies.

Demographic transformation, the third fundamental change shaping the development of Latin America in the early $21^{\text {st }}$ century, is placing new demands on governments as they grapple with globalization strategies. Overall population growth rates continue to decline in the region, with reductions in fertility rates, increases in contraceptive prevalence, improved female literacy, better health care, and greater female participation in the work force as key contributing factors. However, the age structure of the population in many countries, where up to fifty percent of the population is aged twentyfive and under (Mexico, for example), suggests that demographic growth potential will remain high over the next few decades. As a result, the sheer volume of people entering the workforce over 
the coming decades may well outpace the ability of the globalized economy to create new jobs, especially as new centers of high-tech employment emerge in regions such as South Asia, Eastern Europe, and China. A further demographic challenge for those countries that have unequivocally embraced globalization strategies is the changing composition of dependency ratios. One of the key demographic characteristics of economically advanced societies is an increase in the percent of the population over sixty years old.

As life expectancies increase throughout Latin America (up to an average of nearly seventy years in the late 1990s) and medical technologies continue to improve the quality of life, the elderly cohort likely will place a greater economic burden on governments and societies. Estimates suggest that people over sixtyfive years old now represent twentyfive percent of the dependent population in Latin America, up from less than ten percent in 1975 (ECLAC, 2000; Sen, 1994; World Bank, 2000). Mexico is projected to have nearly twenty million people over sixty years of age in 2025, up from five million in 1990, with Brazil (36 million) and Argentina (eight million) experiencing similar rates of increase by 2025 (Lloyd-Sherlock, 1997). These demographic changes are occurring within the framework of a neoliberal welfare ideology that has produced sweeping social security and other public welfare reforms in recent years.

A fourth fundamental change in the shift towards a more globalized economy is the growing differentiation of people and communities within Latin America, both across the entire region and within individual countries. The development gap between, for example, Chile and Haiti has widened dramatically since the 1980s, while economic growth in the littoral of Argentina (Buenos Aires and the development corridor from Rosario to La Plata), for instance, has far outpaced growth in the increasingly impoverished Northwest region. Between 1975 and 1995, the gap between the six poorest countries in Latin America and six selected core economies widened dramatically (Table 1). Moreover, the Per Capita Income ratio also has widened between the six richest and poorest economies in Latin America and between the six richest economies in Latin America and the six selected core economies. Preliminary Gross National Income figures for 2002 suggest a slight narrowing of the gap for the $\mathrm{A}: \mathrm{B}$ and $\mathrm{A}: \mathrm{C}$ ratios, but no significant improvement in the gap between Latin America's richest and poorest economies (B:C) (ECLAC, 2000; World Bank, 2004). A widening income or wealth gap also is evident within individual countries. In Chile, forty percent of the national income is earned by the top ten percent of the population, while the lowest forty percent earn only fifteen percent of the income. Brazil experiences even greater income inequality, with the lowest forty percent of the population earning about seven percent of the national income, compared to the over $50 \%$ share gained by the top ten percent of Brazilian society (World Bank, 2000).

Similar patterns of social polarization are being experienced across the globe, particularly in Sub-Saharan Africa where over one-quarter of a billion people live in poverty (Harsch, 2003; World Bank, 2004). The complex mosaic of globalization's development impact is characterized by the emergence of marginalized enclaves where people and communities are unable to gain access to the global economy's productive processes (Mittelman, 1996). How can these local communities and regions demarginalize when state policy options are extremely constrained by the forces of globalization? Although social polarization as a development condition has long been evident in Latin American societies, the current trend appears to be exacerbated because those social groups with specific skills or capital benefit from links to the global economy, while those lacking the necessary skills or capital become increasingly detached. Neoliberal reforms have not addressed such social concerns directly because the policy priorities have been macroeconomic in nature and not geared toward addressing poverty, inequality, or the redistribution of access to skills, capital, and global opportunities. 


\begin{tabular}{|c|c|c|c|c|c|c|}
\hline \multicolumn{2}{|c|}{$\begin{array}{c}\text { PCI of the } \\
\text { PCI of Six Core } \\
\text { Economies }\end{array}$} & $\begin{array}{c}\text { PCI of the } \\
\text { Lot Six } \\
\text { Lmerican } \\
\text { Economies } \\
\text { in GNP }\end{array}$ & $\begin{array}{c}\text { Bottom Six } \\
\text { Latin } \\
\text { American } \\
\text { Economies } \\
\text { in GNP }\end{array}$ & \multicolumn{4}{|c|}{ Ratios } \\
\hline Year & A, (US \$) & B, (US \$) & C, (US \$) & A:B & B:C & A:C \\
\hline 1975 & 7,899 & 1,602 & 676 & $4.9: 1$ & $2.4: 1$ & $11.7: 1$ \\
\hline 1995 & 27,870 & 4,105 & 917 & $6.9: 1$ & $4.4: 1$ & $30.4: 1$ \\
\hline 2002 & 26,497 & 4,273 & 1,038 & $6.2: 1$ & $4.1: 1$ & $25.5 .: 1$ \\
\hline
\end{tabular}

Table 1. Polarization in the World Economy 1975-2002

Source: Gwynne and Kay (2004: 5), World Bank (2004).

PCI = Per Capita Income.

$\mathrm{A}=$ U.S., Japan, Germany, Britain, France, and Italy.

$\mathrm{B}=$ Argentina, Brazil, Chile, Mexico, Uruguay, and Venezuela.

C = Bolivia, Ecuador, Guatemala, Haiti, Honduras, and Nicaragua.

2002 data calculated using the World Bank Atlas Method of Gross National Income.

As Sheahan (1997:9) puts it, neoliberal policies 'do not in principle rule out redistributing assets for the sake of equalization, but their spirit certainly goes against it.' The theory behind neoliberalism is that macroeconomic stability and greater efficiency will favor economic growth, which in the long term should reduce poverty and inequality and improve access to capital, skills, and opportunities.

Latin America's fifth fundamental force of change is intimately related to the first four. Neoliberal reforms and the drive towards free-market economies within the context of globalization have placed renewed pressure on the physical environment and on natural resource inventories. No space or place in Latin America is immune from the impacts of resource demands, whether it is petroleum exploration in the remotest corner of the Amazon Basin or subsistence agriculture in the densely populated highlands of the Andes. The globalization of the region's economies has expanded trade and investment relationships, primarily in non-manufacturing exports such as agriculture, mining, fishing, forestry, and ranching. During the 1990 s, primary products continued to dominate the mix of total merchandise exports in the majority of Latin American countries; only Mexico $(23 \%)$ and Brazil (45\%) recorded values below fifty percent (ECLAC, 1999; Gwynne and Kay, 1999).

An emphasis on the export of natural resources has encouraged the incorporation of ever-increasing hectares of land into the resource-extraction economy, with significant impacts on the environment. Moreover, growing social polarization, rural-urban migration, industrialized and mechanized farming, rapid urban expansion, and the ideologies of capitalist consumption have stretched the limits of environmental sustainability to crisis point, particularly in large urban areas. Globalization has accelerated the pace of environmental degradation, raised new challenges for sustainable development policymakers, and questioned the traditional relationships between economic growth, social justice, and environmental quality (Sachs, 1999; Zimmerer and Carter 2002).

The final fundamental force of change involves a profound restructuring of timespace relationships in the global system. Innovative technological advances in transport and communica-tion since the 1970s have altered radically the cost, speed, security, and 
flexibility of interaction across the planet. Long-range jumbo jets, giant container ships, supertankers, satellites, high-speed trains, and computers, among other advances, enable complex global organizations of production, distribution, and consumption to function in an efficient and integrated manner. People, goods, information, capital, and ideas flow relatively unimpeded across time and space and have the potential to reshape local conditions in profound and often unintended ways. No corner of Latin America is immune to the influences of restructured transport and communication systems and networks, especially in terms of the impact of radio, television, and video on the attitudes, aspirations, and cultural values of millions of rural and urban people (Loker, 1999; Sagasti, 1995). Within the context of globalization, Sagasti (1995: 600) argues that computerization particularly has created a great divide between those with the capacity to 'generate, acquire, disseminate, and utilize knowledge, both traditional and scientific,' and those without. Thus, full participation in globaliza-tion can be defined in terms of knowledge producers versus knowledge consumers and in terms of those who have accessibility and mobility within the global system and those who do not. As transport, communication, and information technologies link Latin American intellectuals and the elite more closely to the global community, arguably they draw 'farther away from the concerns of their own society, reproducing the global divide' at both the national and local levels (Loker, 1999: 26).

In the broader context of this paradigmatic shift towards globalization and all that it entails, as suggested by the preceding six fundamental forces of change, Latin America is undergoing a political, social, economic, and cultural metamorphosis. Yet change does not occur without disrupt-tion or conflict. Across the region, from the maquiladora zones of the Mexican borderlands to the export-oriented agricultural valleys of central Chile, globalization forces are driving the 'earthquakes and volcanic eruptions' that are reshaping life and livelihood, people and place, and society and nation. These short-term changes to Latin America's socioeconomic landscapes may well determine to a significant degree the long-term success of neoliberalism and globalization in bringing a more equitable and sustainable level of development to the region.

\section{Earthquakes and Volcanic Eruptions: New Directions and Familiar Crises for Latin America}

There is little debate that globalization is transforming Latin America in myriad ways, both positively and negatively. As the region embarks on a development path that will take people and communities in new directions over the next several decades, many familiar development crises remain unresolved. As the region moves toward the future, it faces not only the long-term challenges presented by neoliberal and globalization strategies but also the short-term socio-economic 'earthquakes and volcanic eruptions' that are occurring as a consequence of adopting these strategies. Although the impacts of globalization are myriad and diverse, six specific issues are identified as the most critical 'earthquakes and volcanic eruptions' reshaping the Latin American socioeconomic landscape in the first decades of the $21^{\text {st }}$ century: social polarization; democratiza-tion; migration and labor flow; cultural identity; accessibility and mobility; and environmental stress. An exploration of these six short-term impacts of globalization serves to crystallize the meeting of the global and the local (GLOCAL) and to help place in context the contradictions embedded in globalism.

Growing Polarization of Society: Globalization's fundamental ideology is that a rising tide lifts all boats. Neoliberal reforms are viewed by many throughout the region as im- 
perative for long-term development, and the negative social impacts being experienced by millions are explained away as simply short-term adjustments to the new economic conditions that soon will be overcome. There can be little doubt, however, that serious fraying of the social fabric is occurring throughout Latin America today; witness Argentina's recent economic collapse, Haiti's ongoing turmoil, Bolivia's popular discontent, and the ongoing struggles in Colombia. Over forty percent of the region's population is considered poor, and the absolute numbers in poverty have grown from 120 million in 1970 to over 220 million at the beginning of the new millennium (ECLAC, 2000; World Bank 2004). For example, despite Fujimori's neoliberal development policies in Peru during the late-1990s, over half of the country's total population still lives in poverty, with more than five million people estimated to be in extreme poverty. Forty percent of Peruvians lack adequate access to basic human needs (potable water, electricity, waste removal, health, and education), and over five million earn less than the equivalent of US $\$ 1$ per day (World Bank, 2000; Zevallos, 1997). Moreover, poverty has become a major urban problem as well as an ongoing and significant rural development challenge.

Analysts of social polarization in the region argue that globalization has vested the board-rooms of multinational corporations with immense power over the daily lives of rural and urban dwellers alike. Globalization is seen as 'econocentric, technocentric [and] commodocentric,' abstracted from the social cultural context in which economies, technologies, and commodities operate (Cernea, 1996: 15). Indeed, many Latin American governments have turned increasingly towards market-driven forms of social support in an attempt to reduce the state's long-term financial commitment to the welfare of society. The upper middle and elite sectors of society who are able to engage with globalization can afford the high cost of private healthcare, retirement programs, education, and skill development, whereas the poorer majority must fend for itself within an increasingly inadequately funded and declining public welfare system (Bulmer-Thomas, 1996; Gwynne and Kay, 1999; Lloyd-Sherlock, 1997). Throughout the past twenty years of neoliberal reforms in Latin America, the upper twenty percent of society has benefited substantially in terms of income distribution, the middle forty percent has remained static or declined slightly, while the lower forty percent has seen its share of national income decline consistently (ECLAC, 1999; World Bank, 2000, 2004).

Trade liberalization, labor-market adjustments, and fiscal reform, the backbone of globalization strategies in Latin America, are exacerbating social polarization in several major areas (Bulmer-Thomas, 1996). First, unemployment rates have grown dramatically as public sector employment is cut and domestic companies are forced to 'downsize' their workforce in the face of increased international competition in local economies. Those with the skills, capital, and training needed to take advantage of the opportunities presented by globalization find employment, while those without the necessary attributes drift into the informal economy (underemployment) or become unemployed. Second, downward pressure on wage-labor rates as a consequence of globalization tends to reduce the real minimum wage and thus the level of household income for the majority. This, in turn, widens the gap between average household income and the cost of a basic 'basket of food' needed to support that household. Third, the urban formal economy continues to shrink in many of the regions largest cities and the informal economy has expanded as structural adjustment programs bring greater production flexibility to the marketplace. Small-scale enterprises often lack access to the capital, skills, and distribution systems necessary to compete in a globalized local and national economy. Fourth, agricultural policies that are export-oriented and geared toward production rationalization are exacerbating the marginalization of the rural poor. Many rural communities have been dispossessed from subsistence land, the average farm size has declined, and many rural 
workers are being forced to seek wage-labor employment, primarily in urban areas (Loker, 1999). Finally, the time-space compression technologies that drive globalization are accessible generally to the elite segment of society and not to the poorer majority. Lack of accessibility and mobility for the majority widens the development gap between the haves and the have-nots and leads to declining opportunities in the social, economic, and political spheres.

Limited Democratization: Although globalization has exacerbated social polarization and fostered greater levels of social inequality in Latin America, neoliberal restructuring appears to be linked to an emerging political equality that has come from the expansion of democratization. Herein lies the paradox of what can be termed limited democratization.' Improvements in the social and material welfare of society are deemed central to the development of greater political equality and thus democracy. Yet throughout Latin America, many welfare systems have been undermined and social justice appears to have fallen by the wayside as a policy objective. At the same time, globalization appears to have weakened the power of the state to influence the direction of neoliberal policies. Critics are that neoliberalism has created a 'hollowed out' state, where most economic decisions now are made by the market, by corporations, and by newly emerging global or regional institutions (WTO, GATT, NAFTA, MERCOSUR, etc.) (Gray, 1998). This leaves little policy room for governments to develop social programs aimed at reducing unemployment, poverty, and the erosion of basic public services. Indeed, the current neoliberal economic conception of globalization allows for much greater tolerance of social inequality than in recent history, which in turn leads to the erosion of political responsibility and political equality. Global capitalism is not held accountable to elected state or local officials, which is a further contradiction with the emerging preference for electoral democracy.

Globalization in Latin America has become the most efficient way for governments and consumers to express their economic preferences, and it appears to have relegated citizenship and political participation mostly to elections and voting. Tax breaks and relentless competition are used as tools to attract new investment, with most important political and socioeconomic decisions now made by the global elite, beyond the influence and reach of the vast majority of Latin America's citizens. As O'Donnell (1996:45) observed, '...for large sections of the population, basic liberal freedoms are denied or recurrently trampled [and].... individuals are citizens in relation to the only institution that functions close to what its formal rules prescribe, elections. In the rest, only the members of a privileged minority are full citizens.' Privatization and other neoliberal policies also have accelerated political-economic corruption, which has weakened the 'prestige' of democracy, strengthened the general level of political apathy, and encouraged the depoliticization of society. As a result, the most serious immediate threats to democratic development in Latin America are poor management of national affairs (desgobierno), conspicuous political corruption, the abandonment of social justice as a legitimate development objective, and the political disenfranchisement of vast segments of the region's citizenry.

Opportunistic Migration and Labor Flow: International flows of labor always have been a defining characteristic of globalization processes, from the historic period down to the present day. Over the past two decades, however, the global restructuring of production has changed both the magnitude and geography of migration, particularly in terms of labor flows from the economies of the South (Latin America, Africa, and parts of Asia) to the advanced capitalist countries of the North. In Latin America over the past 
twenty years, most significant labor flows have occurred between Latin American countries or from the region to North America. Yet the transnational migration flows that affect Latin America are not without political and social conflict. Despite the globalization and neoliberal mantra of promoting the free movement of 'people, goods, capital, and information' to facilitate freer trade, many governments increasingly are resistant to transborder labor flows and try very hard to limit both legal and illegal migration. The 1,950-mile Mexico-U.S. border, probably the most heavily militarized border between two democracies in the world, is a visceral reminder of the sharp divide in economic opportunity, quality of life, and migration policy that shapes the labor flow dynamic and generates significant political and cultural conflict. Cross-border migration also is viewed as a significant political, economic, and cultural problem between neighboring Latin American countries. During the mid-1990s in Argentina, for example, both then-President Menem and the secretary-general of the Confederación General del Trabajo blamed an influx of foreign workers for the country's high rate of unemployment and argued for legislation to restrict migration (Latin American Weekly Report 1995). Even rural-urban migration has become problematic in most countries as urban environments become migrant-saturated and unable to fulfill the expectations of those that arrive from the countryside. Many researchers have argued that in order to staunch the flow of migrants to the cities, the rural realm should be more than just a 'warehouse' for the poor (Loker, 1999). Poverty must be addressed in situ rather than exporting it to cities or across national borders. However, migration from poorer to wealthier regions has had significant positive influences throughout Latin America in terms of remittances, flows of ideas, entrepreneurialism, and the diffusion of technology and intellectual capital (Babcock and Conway, 2000; Jokisch,1997)

Despite the positive impacts of remittances, flexible labor markets and internationally mobile capital not only have disrupted households and communities by encouraging migration, they also have changed the nature of job creation, which itself can be disruptive of families and communities. While job creation generally is a good thing, many of the industrial jobs associated with globalization are characterized by a minimum level of skill, low wages, few or no employee benefits, they are female-dominated, and come with limited possibilities for promotion and personal development (Cravey, 1998). In addition, these jobs are changing the social role of many Latin American women; as they move from farm to assembly plants, they become more central to the household economic enterprise (Gwynne and Kay, 2004). Globalization has increased wage-labor competition across the region, with neoliberal restructuring pitting workers and localities against each other in a 'race to the bottom' to provide inexpensive and compliant labor (Brecher and Costello, 1994). Downward pressure on wages in Argentina, for example, is seen as a critical component of neoliberal restructuring and key to helping the country become more competitive in the regional and global economy. In 1995, President Menem argued that Argentine workers were significantly overpaid compared to other Latin American workforces, which not only attracted Paraguayans, Bolivians, and Chileans to work in Argentina but also made the country's industries less competitive in the global marketplace (Business Week 1995). This type of rhetoric creates regional friction and works against long-term socio-economic integration.

Conflicting Socio-Cultural Identities: Sociocultural identities have always been influenced to some degree by external forces, either directly through colonization and imperialism or indirectly by trade and other interactions (Gwynne and Kay, 2004). The difference today is that ultra-modernist globalization is facilitating the rapid diffusion of cultural images, products, artifacts, and ideas around the world, which in many ways seems to 
be overwhelming indigenous technical and social knowledge. Globalization is defining new standards for what is considered a desirable lifestyle, it is creating new contexts for choices about 'wants' versus 'needs,' and it is establishing new definitions of success. Thus, argues Véliz (1994), in order to participate fully and successfully in globalization, Latin America must abandon its historical identity and embrace neoliberalism. Latin America's development failures can be traced to an embedded aversion to risk and change, to distrust of new ideas and technologies, to political and economic preferences for stability and central control, and to an unquestioned respect for social status, hierarchies, and old loyalties. Sociocultural characteristics such as clientelism, ideological traditionalism, authoritarianism, and racism are seen as anti-modernist and barriers to the full incorporation of Latin Americans into the globalized world.

Globalization is creating a new kind of Latin American sociocultural identity, one that is constructed by individual success, innovative entrepreneurialism, the conspicuous consumption of global products, secularization, privatized social welfare, and international accessibility and mobility. Political-economic values such as state-sponsored welfare, justice, industrial development, full employment, national planning, and centralism no longer are deemed viable in the race to become a 'winner' in the globalization competition (Larrain, 1999). The changing identities encouraged by neoliberalism are particularly evident in Latin America's cities, in part because at the beginning of the 21 st century the majority ( 80 percent) of Latin Americans are urbanites. Twentieth century industrial and urban biases to socio-cultural development in the region have been exacerbated by globalization, as the dynamism of economic change rests on cities as the command and control centers of the global system (Knox and Taylor, 1995). As urban wage labor becomes increasingly important, and as globalization draws people into more varied spheres of socio-cultural interaction, either vicariously through mass communication or experientially through migration, urban social, political, and economic identities become further fragmented. Across the region, socio-cultural urban space is being partitioned ever more rigidly, both perceptually and physically, between protected areas for the globalized elite and insecure areas for the non-globalized majority (Rotker, 2002). Such fragmentation may well foster increased urban delinquency, intraclass violence, a weakening of grassroots social movements, political apathy, and the general disarticulation and demobilization of civil society.

Adverse Accessibility and Mobility: Transport and communication form the foundation of ultra-modernist globalization because they not only facilitate the rapid transfer of capital, goods, people, ideas, and information across the planet but they also shape the accessibility and mobility patterns of individuals and communities. New technologies in the transport and communication arena have revolutionized socioeconomic interaction across space and time and they are driving the dissemination of the knowledge that fosters further technological innovation. Yet despite the significant advances in transport and communication technologies in recent decades, Latin America faces two serious crises in accessibility and mobility (Keeling, 2002). The first is the region's tremendous infrastructural deficit, which is severely limiting the ability of countries, communities, and individuals to participate more successfully in the processes of globalization. Inadequate telecommunications, roads, railroads, port facilities, and public transport systems across the region are stifling the ability of communities to engage with the opportunities presented by globalization. For example, at least one million kilometers of paved roads requiring an investment of hundreds of billions of dollars are needed over the next decade if Latin America is to meet the challenge of hemispheric economic integration and 
local socioeconomic development. This multi-billion dollar deficit in transport and communication infrastructure is perhaps the most critical development challenge for the region and it remains the Achilles heel of Latin America's engagement with the ideology of globalization.

Second, millions of Latin Americans suffer today from inadequate accessibility and mobility, both in terms of their ability to access new opportunities and services and their physical mobility in rural or urban environments. Globalization has restructured the geography of economic opportunity, which, in turn, has reshaped the spatial and temporal patterns of accessibility and mobility demands. Poor access to the marketplace, to needed public services, to credit, to new economic opportunities, or to the resources and skills needed to participate in the global economy further exacerbates social polarization and leads to individual and community disarticulation from whatever development benefits might flow from globalization. Those who are well-connected can improve their circumstances, while those who are disconnected fall even further behind.

Lower Environmental Quality: Of all the 'earthquakes and volcanic eruptions' that currently are reshaping the socio-cultural landscape in Latin America, the ongoing and worsening degradation of the physical environment perhaps is the most serious immediate threat to development in the region. Moreover, deteriorating environmental conditions do not discriminate by social strata, location, or economic system - poor-quality air is breathed by both rich and poor, while air pollution recognizes no political boundary. Although international attention has focused primarily on broad issues such as the destruction of the rainforest, local concerns are directed primarily towards the daily hazards to human health and wellbeing such as non-potable water, air pollution, soil degradation, inadequate sewage treatment, and solid waste removal. Governments, business leaders, and the globalization strategists assure critics that the solution to environmental problems 'lies in pursuing even more single-mindedly the liberalization policies that produced these problems' (Power, 1997: 77). Free-trade advocates, for example, argue that neoliberal policies will replace aging, inefficient, and polluting factories with more efficient and environmentally friendly production systems, leading to cleaner air and rising incomes. Critics argue that globalization is not conducive to protection of the environment because competition forces countries to neglect long-term environ-mental safeguards for shortterm economic benefits (Roberts, 1996). Environmental concerns do not fit within the neoliberal paradigm; they are an epistemological and policy blind spot (Loker, 1999).

Latin America's continued focus on resource exploitation, a condition reinforced by the comparative-advantage logic of globalization, is placing ever-greater stress on ecosystems and local environments. Many new 'nontraditional' agricultural products are financed, developed, and exported before any accurate ecological evidence has been generated that assesses the sustainability or negative consequences of new production systems. Exploiting water aquifers with new technologies for expanded vegetable production or increasing the use of fertilizer and pesticides often is unsustainable over the long term. Murray's (1998) examination of fruit cultivation for export in Chile has raised important questions about agricultural sustainability, particularly in terms of water shortages and contamination, soil salinity, and declining soil fertility. Export-oriented development policies also encourage households to colonize environmentally sensitive 'frontier' zones, leading to social conflict and ecological degradation (Durham, 1995). Other immediate threats to the rural population include the unsustainable intensification of agricultural practices from increased population, land and capital shortage, and excessive chemical inputs. Threats to Latin America's urban population are no less immediate and serious than those experienced in the rural areas, and are perhaps even more localized. Today, 
over 100 million Latin Americans live in urban conditions that pose a considerable threat to their daily lives (Gwynne and Kay, 2004). Unsafe water, poor-quality shelter, unsafe housing locations, inadequate waste and sanitation services, and a lack of access to health services are just a few of the daily environmental challenges faced by Latin America's poorer urbanites.

In summary, the long-term fundamental forces of change emerging under conditions of globalization are driving a regionalized and localized restructuring of socio-economic landscapes. These regional and local 'earthquakes and volcanic eruptions' are having different impacts on different places, particularly in terms of the depth, breadth, and type of impacts, in part because of the spatial heterogeneity embedded in the national territory of individual Latin American countries. Although these short-term changes, some positive and some negative, are being experienced throughout Latin America, it is local conditions and local communities structured within a regional framework that determine the level and impact of engagement with neoliberalism and globalization.

\section{Rethinking the Framework, Restructuring the Analysis?}

Since the late-1970s, many Latin American governments and the business elite have adopted the ideologies and policies of globalization in an attempt to alter the longterm direction of socio-economic development in the region. Macroeconomic statistics and indices that measure inflation, employment restructuring, trade flows, capital investment rates, currency stability, and export linkages point to some level of success in changing the course of development in Latin America for the better. Globalization advocates rely on these statistics as evidence that the policies of neoliberal restructuring are working and that the short-term development pain experienced by millions across the region will give way ultimately to long-term development gain. Globalization critics argue that the macroeconomic or global indices of success mask the serious local upheaval (the socioeconomic earthquakes and volcanic eruptions) suffered by the region's majority and that the short-term socioeconomic pain afflicting the majority of Latin Americans will give way to long-term entrenched development pain. To paraphrase once again Brecher and Costello's (1994) argument, is Latin America integrating into the global village or is the region fast becoming a victim of global pillage?

Globalization policies have accentuated the socioeconomic importance of the primary city or city-region in each Latin American country, with the consequence that most gains in labor productivity, economic growth, technology improvements, and employment restructuring have occurred in the core area. Beyond the core region, development prosperity under the conditions of globalization has been linked to the ability of a region or community to attract capital, to produce goods for the export market, and to offer a comparative advantage in the cost of labor. Those regions without this ability have suffered economic stagnation, labor losses, capital shrinkage, and further national and regional isolation. Yet as Gwynne and Kay (2004: 21) point out, it is most often 'at the regional and local scales of analysis that the impacts of globalization can best be seen in terms of changing social relations' and in terms of sustainable development. Regional economies and societies are an aggregation of the competitive advantages and economic destinies of individual localities and, as such, are critical collectives of interdependent socioeconomic activities (Scott, 1998). Therefore, the immediate policy task for Latin America countries ought to be a clearer democratic articulation of the social, political, and economic development goals that need to be achieved at the regional and local level within the broader context of globalization policies. This requires a set of transparent 
institutional structures that can cooperate on, coordinate, and integrate the type of strategic planning needed to articulate the global with the local and to allow all of Latin America's disparate regions and countries to benefit fully from globalization. Failure to establish this type of framework for regional and local development likely will result in further damage to the socio-economic landscape as a consequence of globalization's 'earthquakes and volcanic eruptions.' Moreover, it will further deepen the problem of lagging development that today restricts millions of Latin Americans from achieving their full life potential.

A key theme that emerges from this discussion of Latin America's engagement with globalization is that, in many instances, the 'global' seems to have overwhelmed the 'local' completely as a framework or context for socio-economic policymaking. As the ideologies and technologies of globalization link governments, planners, and the elite more closely to the global community, they tend to disarticulate these same groups from the local concerns of people and communities. Thus, in order to rethink the broader development implications of globalization and to restructure the ways in which globalization forces affect the socio-economic landscape, governments, planners, and the elite must move towards a conceptualization of sustainable development that merges the global and the local in the policy-making process. Merging the two frames of reference into one can be termed 'glocalization' or a global-local approach to policymaking, and the broader analytical context for this approach should be regional in nature. In other words, policymakers should move away from a conceptualization of national development that sees the socio-economic landscape as homogenous within the global system to a conceptualization of national development that treats the socio-economic landscape as regionally based, heterogeneous, and imbued with local conditions and contradictions.

Finally, we need to rethink the meta-theoretical framework of globalization in policy formation because the use of the term has become problematic and value-laden, and it carries powerful ideologies that tend to refocus societies and economies outward toward a broader context. Glocalization, in contrast, recognizes the wider spatial forces of development and change, but also focuses on the local implications and adaptations. This concept of linking the global and the local conceptually and empirically - thinking globally and acting locally - has been in the lexicon of academics and others for many years, yet it seems to have diverted attention away from actually acting locally because the global has become so overwhelming. The issues presented in this paper suggest that the concept be rephrased to 'thinking locally within a global framework, while acting globally within a local framework.' Such an approach may well help Latin Americans to structure the forces of globalization in a more positive and proactive manner for people, communities, and places.

\section{References}

Appadurai, Arjun (ed.). 2003. Globalization. Durham, NC: Duke University Press.

Babcock, E. C. and D. Conway. 2000. Why international migration has important consequences for the development of Belize. CLAG Yearbook 26: 71-86.

Bauman, Z. 1998. Globalization: The Human Consequences. New York: Columbia University Press.

Brecher, J. and T. Costello 1994. Global Village or Global Pillage: Economic Reconstruction from the Bottom Up. Boston: South End Press. 
Bulmer-Thomas, V. (ed.). 1996. The New Economic Model in Latin America and its Impact on Income Distribution and Poverty. London: MacMillan.

Business Week. 1995. Menem: The Devil's real name is devaluation. August 28: 45.

Cardoso, F. 1982. Dependency and development in Latin America, in H. Alavi and T. Shanin (eds.) Introduction to the Sociology of Developing Societies, pp. 112-127. NY: Monthly Review Press.

Cernea, M. 1996. Social Organization and Development Anthropology. Washington, DC: World Bank, Environmentally Sustainable Development Studies and Monograph Series 6.

Cox, R.W. 1996. A perspective on globalization, in J. H. Mittelman (ed.) Globalization: Critical Reflections, pp. 21-30. Boulder: Lynne Rienner.

Cravey, A. J. 1998. Women and Work in Mexico's Maquiladoras. Lanham, MD: Rowman \& Littlefield.

Durham, W. 1995. Political ecology and environmental destruction in Latin America, in M. Painter and W. Durham (eds) The Social Causes of Environmental Destruction in Latin America, pp. 249-64. Ann Arbor: University of Michigan Press.

ECLAC 1999. Statistical Yearbook for Latin America and the Caribbean, 1999. Santiago: Economic Commission for Latin America and the Caribbean (ECLAC).

2000. Social Panorama of Latin America, 1999-2000. Santiago: Economic Commission for Latin America and the Caribbean (ECLAC).

Edwards, S. 1995. Crisis and Reform in Latin America: From Despair to Hope. New York: Oxford University Press.

Frank, A. G. 1969. Capitalism and Underdevelopment in Latin America. NY: Monthly Review Press.

Friedman, T. L. 1999. The Lexus and the Olive Tree: Understanding Globalization. New York: Farrar, Straus, Giroux.

Giddens, A. 1990. The Consequences of Modernity. Stanford: Stanford University Press.

Gray, John 1998. False Dawn: The Delusions of Global Capitalism. London: The New Press.

Gwynne, R. N. and C. Kay. 2004. Latin America Transformed: Globalization and Modernity, $2^{\text {nd }}$ edn. London: Arnold.

Haggard, S. and R. R. Kaufman. 1996. The Political Economy of Democratic Transitions. Princeton: Princeton University Press.

Harsch, Ernest. 2003. Africa beyond famine: New strategies needed to combat hunger, disease and rural poverty. Africa Recovery 17(1): 1-2. 
Hayes, Margaret. 1998. The impact of market opening on Argentine industry: A survey of corporate impressions, in J.S. Tulchin and A.M. Garland (eds.) Argentina: The Challenges of Modernization, pp. 257-280. Wilmington, DE: Scholarly Resources.

Held, D., A. McGrew, D. Goldblatt, and J. Perraton. 1999. Global Transformations. Cambridge: Polity Press.

Howes, D. (ed.). 1996. Cross-cultural Consumption: Global Markets, Local Realities. London: Routledge.

Jokisch, B. 1997. From labor circulation to international migration: The case of southcentral Ecuador, CLAG Yearbook 23: 63-76.

Kaul, Chandrika (ed.). 1999. Statistical Handbook on Poverty in the Developing World. Westport, CT: Oryx Press.

Keeling, D. J. 2002. Transport Challenges for Latin America in the $21^{\text {st }}$ Century, pp. 77104 in G. Knapp (ed.) Latin America in the 21. Century: Challenges and Solutions. Austin: University of Texas Press.

Kim, Yeong. 2000. What is/isn't americanizing in Seoul? Journal of the Korean Urban Geographical Society 3(1): 81-92.

Knox, P. L. and P. J. Taylor (eds.) 1995. World Cities in a World-System. Cambridge: Cambridge University Press.

Korzeniewicz, R. P. 1997. The deepening differentiation of enterprises, states and households, in W. C. Smith and R. P. Korzeniewicz (eds.) Politics, Social Change, and Economic Restructuring in Latin America, pp. 215-250. Boulder: Lynne Rienner.

Krooth, R. 1995. Mexico, NAFTA, and the Hardships of Progress. London: McFarland.

Larrain, J. 1999. Modernity and identity: Cultural change in Latin America, in R. N. Gwynne and C. Kay (eds.) Latin America Transformed: Globalization and Modernity, pp. 182-202. London: Arnold.

Latin American Weekly Report 1995. London: Latin American Newsletters.

Lechner, F. J. and J. Boli (eds.) 2003. The Globalization Reader, $2^{\text {nd }}$ Edn. New York: Blackwell.

Lloyd, C. 2000. Globalization: Beyond the ultra-modernist narrative to a critical realist perspective on geopolitics in the Cyber Age, International Journal of Urban and Regional Research 24(2): 258-73.

Lloyd-Sherlock, P. 1997. Old Age and Urban Poverty in the Developing World: The Shanty Towns of Buenos Aires. London: Macmillan Press.

Loker, W. M. 1999. Grit in the prosperity machine: Globalization and the rural poor in Latin America, in W. M. Loker (ed.) Globalization and the Rural Poor in Latin America, pp. 939. Boulder: Lynne Rienner. 
Mittelman, J. H. 1994. The globalization challenge: Surviving at the margins, Third World Quarterly 14: 427-43.

1996. The Dynamics of Globalization, in James H. Mittelman (ed.) Globalization: Critical Reflections, pp. 1-20. Boulder: Lynne Rienner.

Murray, W. E. 1998. The globalisation of fruit, neoliberalism, and the question of sustainability: Lessons from Chile, European Journal of Development Research 10(1): 201-27.

O’Donnell, Guillermo. 1996. Illusions about Consolidation, Journal of Democracy 7(2): 3451.

Power, G. 1997. Globalization and its discontents, Development 40(2): 75-80.

Prebisch, R. 1972. International Economics and Development. New York: Academic Press.

Roberts, J. T. 1996. Global restructuring and the environment in Latin America, in R. P. Korzeniewicz and W. C. Smith (eds.) Latin America in the World-Economy, pp. 187-210. London: Praeger.

Robertson, R. 1995. Glocalization: Time-space and homogeneity-heterogeneity, in M. Featherstone, S. Lash, and R. Robertson (eds.) Global Modernities, pp. 25-44. London: Sage.

Rodrik, Dani. 1999. The New Global Economy and Developing Countries: Making Openness Work. Washington, DC: Overseas Development Council.

Rotker, S. (ed.) 2002. Citizens of Fear: Urban Violence in Latin America. New Brunswick: Rutgers University Press.

Sachs, Wolfgang. 1999. Planet Dialectics: Explorations in Environment and Development. London: Zed Books.

Sadowski, Y. 1998. The Myth of Global Chaos. Washington, DC: Brookings Institution Press.

Sagasti, F. 1995. Knowledge and development in a fractured global order, Futures 27(6): 571-610.

Sassen, S. 1998. Globalization and its Discontents. New York: The New Press.

Schwartz, H. 1994. States versus Markets: History, Geography, and the Development of the International Political Economy. New York: St. Martin's Press.

Scott, A. J. 1998. Regions and the World Economy. New York: Oxford University Press.

Sen, K. 1994. Ageing: Debates on Demographic Transition and Social Policy. London: Zed Press.

Sheahan, J. 1997. Effects of liberalization programs on poverty and inequality: Chile, Mexico, and Peru, Latin American Research Review 32(3): 7-37.

Thurow, L. 1996. The Future of Capitalism: How Today's Economic Forces Will Shape Tomorrow's 
World. New York: Morrow.

Tomlinson, J. 2003. Cultural Imperialism, pp. 303-311 in F. Lechner and J. Boli (eds.) The Globalization Reader. New York: Blackwell. 1999. Globalization and Culture. Chicago: University of Chicago Press.

Véliz, C. 1994. The New World of the Gothic Fox: Culture and Economy in English and Spanish America. Berkeley:University of California Press.

Wallerstein, I. 1979. The Capitalist World-Economy. New York: Cambridge University Press. 1974. The Modern World System: Capitalist Agriculture and the Origins of the European World-Economy in the Sixteenth Century. New York: Academic Press.

Watson, J. L. (ed.) 1997. Golden Arches East: McDonald's in East Asia. Stanford: Stanford University Press.

World Bank. 2000. World Development Report 2000/2001. http://www.worldbank.org/poverty/ wdrpoverty/.

2004. Data and Statistics, World Bank Group. http://www.worldbank.org/ data/ countrydata/countrydata.html.

Zevallos, J. V. 1997. Estrategias para reducir la pobreza en América Latina y el Caribe. Quito: Programa de las Naciones Unidas para el Desarrollo (PNUD).

Zimmerer, K. S. and E. D. Carter. 2002. Conservation and Sustainability in Latin America and the Caribbean, pp. 207-249 in G. Knapp (ed.) Latin America in the 21.t Century: Challenges and Solutions. Austin: University of Texas Press. 